\begin{tabular}{l|c|c}
\hline \hline Vol. 25(4):519-528 & Ocean and Polar Research & December 2003 \\
\hline
\end{tabular}

Article

\title{
Seasonal Dynamics of Marine Benthic Communities in Intertidal Zone of Gwangyang Bay, Southern Coast of Korea
}

\author{
Jong Su Yoo* \\ Research Institute of Marine Science and Technology \\ Korea Maritime University, Busan 606-791, Korea
}

\begin{abstract}
Species composition and community structure of marine benthic community were studied in the intertidal zone of Jijindo Island, Gwangyang Bay. A total of 85 species of benthic marine plants including the 5 Cyanophyta, 9 Chlorophyta, 13 Phaeophyta, 56 Rhodophyta and 2 Magnoliophyta that were listed. The community structure was represented by Gelidium divaricatum in the upper zone, Gelidium divaricatum and Ulva pertusa in the middle, and Ulva pertusa, Chondria crassicaulis, Chondracanthus intermedia and Sargassum thunbergii in the lower intertidal zone. The dominant species in the macrozoobenthic community were Chthamalus challengeri in the upper and middle, Littorina brevicula between the upper and middle, and Mytilus edulis and Crassostrea gigas in the middle and lower intertidal zones. The economic benthic organisms such as Undaria pinnatifida, Mytilus edulis, and Crassostrea gigas found in the lower intertidal zone were frequently disturbed due to their collection by local resident. Therefore, it is necessary to record the correct information pertaining to these cases. The species diversity indices estimated from different sources were quite different. They were 2.22 derived from frequency, 1.67 based on coverage, 2.17 based on sum of frequency and coverage and 2.04 derived from importance value. Species diversity and number of algal species in Gwangyang Bay have noticeably decreased, compared with their previously reported status. It is estimated that their decreases were caused by changes in the marine environment, especially pertaining to the polychaete community resulting from reclamation and dredging activity undertaken for the industrial development.
\end{abstract}

Key words : benthic marine plants, community structure, species diversity, macro-zoobenthos

\section{Introduction}

The rapid economic growth that began in the late $1970 \mathrm{~s}$ has resulted in the formation of many coastal industrial areas and a rapid growth in urban population in main coastal regions of Korea. The reclamation and dredging activities undertaken to create such coastal industrial areas has affected the physical environment of coastal areas themselves. Furthermore, the waste water that is increasing due to increased urban population and factory operations affects marine water quality, which has direct/indirect effects on surrounding marine organisms (Song 1986; Yoo 2003a).

In Gwangyang Bay, fresh water flows into from the northern Seomjin River; the western and southern areas,

*Corresponding author. E-mail : jsyoo@hhu.ac.kr where Yulchon and Yeocheon industrial areas are located, are mainly a flat tidal region with high turbidity; the eastern region is surrounded by Namhaedo Island; the Straits of Noryang form a narrow canal between Hadong and Namhaedo Island. The seawater circulation with oceanic water mainly occurs at the entrance of Gwangyang Bay between Namhaedo Island and Yeosu (Park et al. 1984; Shin and Koh 1990). Such differences in hydrographic conditions causes the micro-environments inside the bay, such as tidal currents and salinity to be geographically different. Thus, Chang et al. (1975) and Lee et al. (1975) have divided Gwangyang Bay into 3 sections based on environmental characteristics.

On the other hand, Gwangyang Bay has changed in its physicochemical marine environment due to the reclamation and dredging activities that have been undertaken to 
construct Yeochen Industrial Zone, Gwangyang Steelworks, Yulchon Industrial Zone, Chonam Industrial Zone, Kwangyang Container Pier, Hadong Thermal Power Plant, etc. since the 1980s. It has been reported that such marine environment change caused a change in the zoobenthic community structure (Jung et al. 1995, 1997; Huh and An 1997). The marine benthic organisms are sensitive to the surrounding environmental changes. Therefore, they are widely used as bioindicators to indicate the environmental conditions of the relevant areas (Blake et al. 1976; Reddy and Rao 1991; Yoo 2003a). A report was issued on benthic marine algae of Gwangyang Bay by Lee et al. (1975) and Lee and Kim (1977) before coastal development took place; and by Song (1986) and Kim et al. (1991) after the development started.

This study has been conducted to find out about the characteristics and dynamics of the intertidal benthic communities in Gwangyang Bay by investigating the number of species and the community structure and to provide data on how the construction and operation of the coastal industrial areas and the extension of the coastal urban areas have affected the community dynamics and species diversity.

\section{Materials and methods}

The investigation for this study was conducted in the intertidal zone of Jijindo Island ( $\left.34^{\circ} 52^{\prime} 30^{\prime \prime} \mathrm{N}, 127^{\circ} 45^{\prime} 55^{\prime \prime} \mathrm{E}\right)$, Gwangyang Bay, at the southern coast of Korea from May 2002 to February 2003 (Fig. 1). Benthic marine plants were collected for an floral study. Samples were fixated with $10 \%$ formalin-seawater, then transported to the laboratory. The transported samples were washed with fresh water, then isolated and identified with the aid of a microscope. The community structure of benthic marine plants was investigated at each layer of the intertidal zone in six sections (A-F), classified on the basis of the differences in environment conditions (Fig. 1). And the vertical zonation of benthic marine organisms was studied by measuring the frequency and coverage of all species inside each quadrat. A $0.5 \mathrm{~m} \times 0.5 \mathrm{~m}$ quadrat was established every 1 meter along the transect line of area $\mathrm{D}$. The frequency and coverage of dominant species in each quadrat were measured, and the average of total relative frequency and coverage calculated from the field survey was represented as an importance value (IV). The algal diversity index ( $\left.\mathrm{H}^{\prime}\right)$ was used to show the stability of the community based on abundance and evenness (Peet 1974), and the Shannon index $\left(\mathrm{H}^{\prime}=-\mathrm{Pi} \Sigma \log \mathrm{Pi}\right)$ was used in this study (Shannon

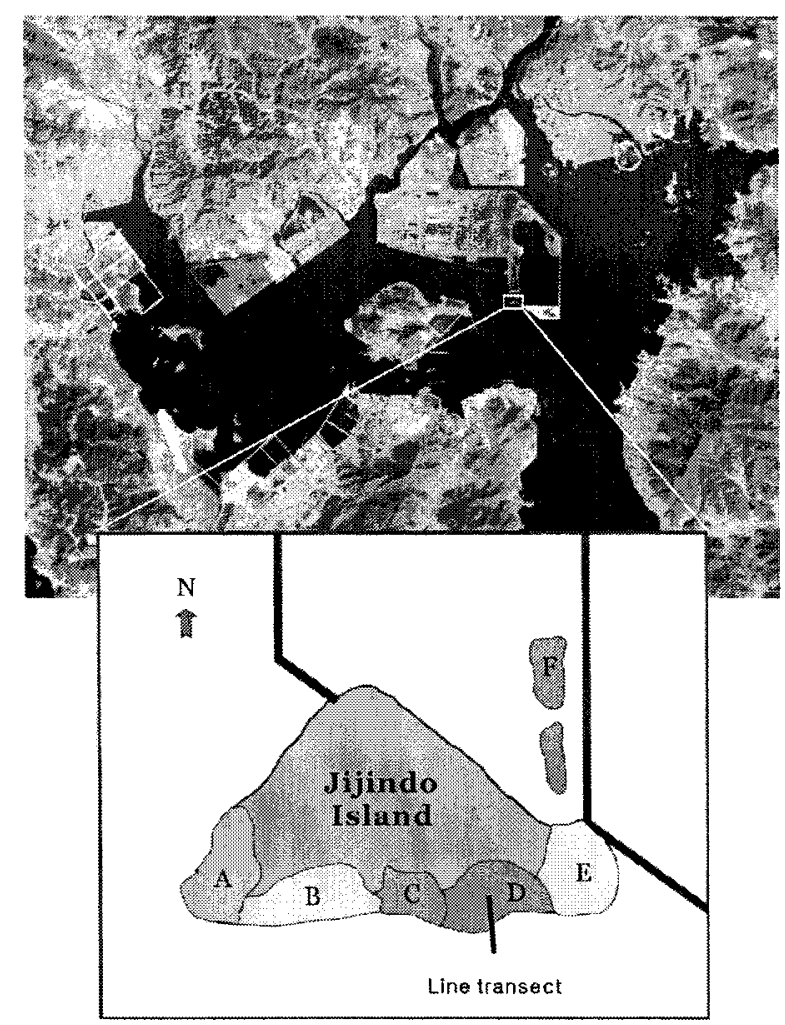

Fig. 1. Map showing the sampling sites in Jijindo Island, Gwangyang Bay.

and Weaver 1949). In addition, the previous floristic data from 1974-1975, 1983-1985 and 1990 were compared with the results of this study, to show the changes in algal diversity before and after industrial development (Lee $e t$ al. 1975; Lee and Kim 1977; Song 1986; Kim et al. 1991). Sфrensen's index was used as an index displaying similarities (Sфrensen 1948).

\section{Results}

There was a total of 85 species consisting of 5 Cyanophyta, 9 Chlorophyta, 13 Phaeophyta, 56 Rhodophyta, and 2 Magnoliophyta (Table 1). There were a total of 60 species in spring, 57 in autumn, 56 in summer, and 50 in winter, which showed that there were more species in the spring season (Table 2). The percentage for divisional composition was $5.9 \%$ for Cyanophyta, 10.6\% for Chlorophyta, 15.3\% for Phaeophyta, 65.9\% for Rhodophyta, and $2.4 \%$ in the case of Magnoliophyta.

The percentage of divisional composition changed according to the season; the percentage of Cyanophyta was high in summer and autumn, but low in spring and 
Table 1. Check list of benthic marine plants observed in Jijindo Island, Gwangyang Bay.

\begin{tabular}{|c|c|c|c|c|c|c|c|c|c|}
\hline Species & Spring & Summer & Autumn & Winter & Species Seasons $S$ & Spring & Summer & Autumn & Winter \\
\hline \multicolumn{10}{|l|}{ Cyanophyta } \\
\hline Entophysalis conferta & & + & + & + & Gelidium pusilum & + & + & + & \\
\hline Lyngbya sp. & + & + & + & & Pteroclada capillacea & + & + & + & + \\
\hline Microcoleus sanctae-crucis & & + & + & & Caulacanthus ustulatus & + & + & + & + \\
\hline Oscillatoria amphibia & + & + & + & + & Chondracanthus intermedia & + & + & + & + \\
\hline Sirocoeum kurzii & & & + & + & Chondracanthus teedii & + & & & \\
\hline Chlorophyta & & & & & Chondracanthus tenellus & + & + & + & + \\
\hline Capsosiphon fulvescens & & + & & & Chondrus ocellatus & + & + & + & + \\
\hline Enteromorpha compressa & + & + & + & + & Hypnea charoides & + & & & \\
\hline Enteromorpha prolifera & & + & + & + & Callophyllis crispata & & + & + & \\
\hline Ulva pertusa & + & + & + & + & Ahnfeltiopsis flabelliformis & + & + & + & + \\
\hline Cladophora conchopheria & + & & & & Stenogramma interrupta & & + & & \\
\hline Cladophora albida & + & + & + & + & Schizymenia dubyi & & + & & \\
\hline Cladophora sp. & & + & + & & Carpopeltis affinis & & & + & + \\
\hline Bryopsis pulmosa & & + & + & + & Grateloupia elliptica & + & & + & + \\
\hline Derbesia marina & + & + & & & Grateloupia filicina & + & + & + & + \\
\hline Phaeophyta & & & & & Grateloupia lanceolata & + & & + & + \\
\hline Ectocarpus arctus & & + & & & Grateloupia okamurae & + & & & \\
\hline Hincksia mitchellae & + & + & & + & Grateloupia turuturu & + & + & + & + \\
\hline Sphacelaria sp. & + & + & + & + & Gracilaria textorii & + & + & + & + \\
\hline Dilophus okamurae & & & + & & Gracilaria verrucosa & + & + & & \\
\hline Myelophycus simplex & & & + & & Plocamium telfairiae & + & & & \\
\hline Colpomenia sinuosa & + & + & + & + & Champia parvula & + & + & + & \\
\hline Undaria pinnatifida & + & & & + & Lomentaria hakodatensis & + & + & + & + \\
\hline Chorda filum & + & & & & Chrysymenia wrightii & + & & & \\
\hline Hizikia fusiformis & + & + & + & + & Campylaephora crassa & + & + & & + \\
\hline Saryassum horneri & + & & + & + & Campylaephora hypnaeoides & + & & & \\
\hline Sargassum fluvellum & + & & & + & Ceramium boydenii & + & & & + \\
\hline Sargassum miyabei & + & & & & Ceramium japonicum & + & + & + & + \\
\hline Sargassum thunbergii & + & + & + & + & Ceramium kondoi & + & + & & \\
\hline Rhodophyta & & & & & Dasya sessilis & & & + & \\
\hline Stylonema alsidii & + & + & + & + & Heterosiphonia japonica & & & + & \\
\hline Bangia atropurpurea & & + & + & & Acrosorium polyneurum & + & + & + & + \\
\hline Porphyra seriata & & & + & & Acrosorium uncinatum & & + & + & \\
\hline Porphyra suborbiculata & & & + & + & Acrosorium yendoi & & + & + & + \\
\hline Porphyra yezoensis & + & & + & + & Erythoglossum minimum & & + & & \\
\hline Acrochaetium densum & & + & & & Chondria crassicaulis & + & + & + & + \\
\hline Amphiroa sp. & & & & + & Chondria dasyphylla & + & & & \\
\hline Corallina officinalis & + & + & + & + & Laurencia intermedia & + & + & + & + \\
\hline Corallina pilulifera & + & + & + & + & Laurencia okamurae & + & + & + & \\
\hline Jania sp. & + & & & & Polysiphonia morrowii & + & + & + & + \\
\hline Pneophyllum zostericolum & + & + & + & + & Symphyocladia latiuscula & + & & & + \\
\hline Titanoderma tumidulum & + & & & & Symphyocladia marchantioides & + & + & + & + \\
\hline Melobesioideaen algae & + & + & + & + & Magnoliophyta & & & & \\
\hline Gelidium amansii & + & + & + & + & Zostera caulescens & + & & & \\
\hline Gelidium divaricatum & + & + & + & + & Zostera marina & + & + & + & + \\
\hline
\end{tabular}


Table 2. The number of marine benthic plants observed in Jijindo Island, Gwanyang Bay.

\begin{tabular}{|c|c|c|c|c|c|}
\hline Species & Spring & Summer & Autumn & Winter & Sum \\
\hline Cyanophyta & 2 & 4 & 5 & 3 & 5 \\
\hline Chlorophyta & 5 & 8 & 6 & 5 & 9 \\
\hline Phaeophyta & 10 & 6 & 7 & 8 & 13 \\
\hline Rhodophyta & 43 & 37 & 38 & 33 & 56 \\
\hline Magnoliophyta & 2 & 1 & 1 & 1 & 2 \\
\hline Sum & 62 & 56 & 57 & 50 & 85 \\
\hline
\end{tabular}

winter; percentages for Chlorophyta were high in summer with little difference noted for other seasons; Phaeophyta, Rhodophyta and Magnoliophyta were high in spring (Fig. 2). Meanwhile, the species observed in all four seasons were a total of 31 species - 1 Cyanophyta, 3 Chlorophyta, 4 Phaeophyta, 22 Rhodophyta and 1 Magnoliophyta which amounted to $36.5 \%$ of the total number of species.

Benthic marine algae, which displayed an importance value not less than 0.5 during this investigation period, is shown in Table 3. Regarding the species with an importance

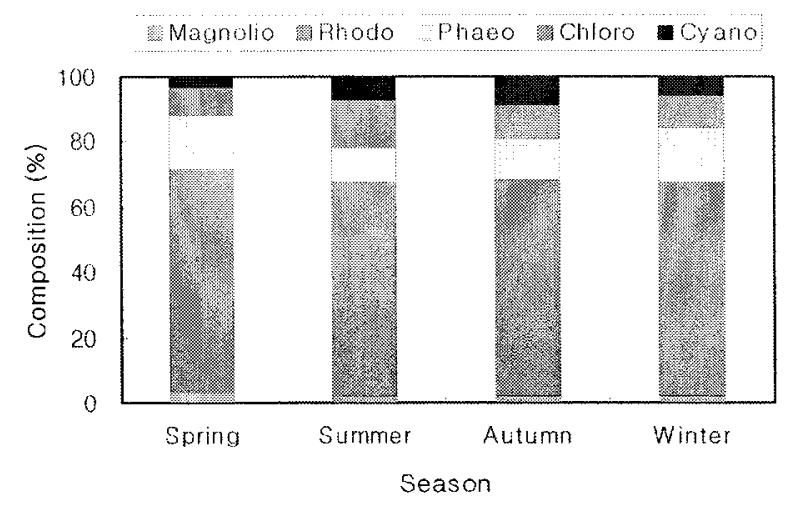

Fig. 2. Seasonal variation in composition of marine benthic plant community in Jijindo Island, Gwangyang Bay.

value not less than 10 as dominant species and the species with an importance value not less than 5 as a subdominant species, Gelidium divaricatum and Ulva pertusa were the dominant species every season; Sargassum thunbergii was added to such species in summer; Chondria crassicaulis was added in winter. The subdominant species were $C$.

Table 3. The importance value (IV) of benthic marine algae by each season and layers of intertidal zone, based on coverage and frequency in Jijindo Island, Gwangyang Bay (U: Upper intertidal zone, M: Middle, L: Lower).

\begin{tabular}{|c|c|c|c|c|c|c|c|c|c|c|c|c|c|c|c|c|}
\hline \multirow{2}{*}{ Species } & \multicolumn{3}{|c|}{ Spring } & \multicolumn{3}{|c|}{ Summer } & \multicolumn{3}{|c|}{ Autumn } & \multicolumn{3}{|c|}{ Winter } & \multicolumn{3}{|c|}{ Average } & \multirow{2}{*}{ Sum } \\
\hline & $\mathbf{U}$ & $\mathbf{M}$ & $\mathbf{L}$ & $\mathbf{U}$ & $\mathbf{M}$ & $\mathbf{L}$ & $\mathbf{U}$ & $\mathbf{M}$ & $\mathbf{L}$ & $\mathbf{U}$ & $\mathbf{M}$ & $\mathbf{L}$ & $\mathbf{U}$ & $\mathbf{M}$ & $\mathbf{L}$ & \\
\hline Gelidium divaricatum & 63.4 & 21.9 & - & 100 & 47.0 & - & 90.6 & 36.5 & 0.2 & 98.3 & 43.6 & - & 88.1 & 37.3 & 0.1 & 125.4 \\
\hline Ulva pertusa & 25.0 & 44.3 & 29.5 & - & 40.3 & 42.2 & 9.6 & 52.6 & 36.3 & 1.7 & 34.0 & 29.5 & 9.1 & 42.8 & 34.4 & 86.2 \\
\hline Chondria crassicaulis & - & 0.3 & 16.0 & - & - & 2.1 & - & 4.2 & 22.8 & - & 6.1 & 32.9 & - & 2.7 & 18.4 & 21.1 \\
\hline Sargassum thunbergii & - & 12.7 & 1.1 & - & 4.4 & 42.5 & - & 2.1 & 1.6 & - & 3.0 & 3.4 & - & 5.5 & 12.2 & 17.7 \\
\hline Chondracanthus intermedia & - & - & 14.3 & - & - & 0.7 & - & 1.3 & 21.0 & - & 5.6 & 17.1 & - & 1.7 & 13.3 & 15.0 \\
\hline Porphyra spp. & 11.6 & 3.8 & 1.0 & - & - & - & - & & 0.2 & - & 1.7 & 0.7 & 2.9 & 1.4 & 0.5 & 4.8 \\
\hline Hizikia fusiformis & - & 0.9 & 0.6 & - & 0.1 & 0.5 & - & 0.3 & 8.0 & - & 1.2 & 6.1 & - & 0.6 & 3.8 & 4.4 \\
\hline Chondrus ocellatus & - & 9.6 & 6.6 & - & - & - & - & - & - & - & - & 0.8 & - & 2.4 & 1.8 & 4.2 \\
\hline Undaria pinatipida & - & - & 13.1 & - & - & - & - & - & - & - & - & 1.6 & - & - & 3.7 & 3.7 \\
\hline Melobesioidean algae & - & 0.2 & 1.4 & - & 0.6 & 2.9 & - & 1.0 & 4.0 & - & 0.6 & 0.0 & - & 0.6 & 2.1 & 2.6 \\
\hline Laurencia intermedia & - & - & 0.9 & - & 1.9 & 7.1 & - & & 0.1 & - & 0.0 & 0.0 & - & 0.5 & 2.0 & 2.5 \\
\hline Corallina spp. & 0.1 & 0.8 & 0.4 & - & 1.1 & 0.7 & - & 0.9 & 1.1 & - & 1.4 & 0.5 & - & 1.0 & 0.7 & 1.7 \\
\hline Colpomenia sinuosa & - & 3.6 & 2.4 & - & - & - & - & - & - & - & - & 1.0 & - & 0.9 & 0.8 & 1.7 \\
\hline Caulacanthus ustulatus & - & - & & - & 4.4 & 0.7 & - & - & - & - & - & 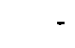 & - & 1.1 & 0.2 & 1.3 \\
\hline Polysiphonia morrowii & - & 0.9 & 0.2 & - & - & - & - & 0.4 & & - & 1.2 & 2.0 & - & 0.6 & 0.6 & 1.2 \\
\hline Gelidium amansii & - & - & 1.5 & - & - & 0.7 & - & - & - & - & - & 1.7 & - & - & 1.0 & 1.0 \\
\hline Sargssum fluvelum & - & 0.2 & 3.4 & - & - & - & - & - & - & - & - & - & - & 0.1 & 0.9 & 0.9 \\
\hline Acrosorium polyneurum & - & 0.4 & 1.2 & - & - & - & - & 0.3 & 0.4 & - & - & 1.4 & - & 0.2 & 0.7 & 0.9 \\
\hline Lomentaria hakodatensis & - & - & & - & - & - & - & 0.3 & 1.8 & - & - & 0.4 & - & 0.1 & 0.6 & 0.6 \\
\hline Grateloupia elliptica & - & - & 1.6 & - & - & - & - & - & 0.1 & - & 0.5 & - & - & 0.1 & 0.4 & 0.6 \\
\hline Ahnfeltiopsis flabelliformis & - & - & 0.2 & - & 0.1 & - & - & - & 1.0 & - & 0.7 & 0.1 & - & 0.2 & 0.3 & 0.5 \\
\hline
\end{tabular}


crassicaulis, Chondrachanthus intermedia, Porphyra spp. and Chondrus ocellatus in spring; $C$. crassicaulis and $C$. intermedia in fall; and $C$. intermedia in winter. Biological zonation was made clear by representative algae such as $G$. divaricatum in the upper tidal zone, $G$. divaricatum and $U$. pertusa in the middle zone, and $U$. pertusa, $C$. crassicaulis, $C$. intermedia and Sargassum thunbergii in the lower zone.

Table 4 shows the community structure of the benthic marine plants of sampling stations (section A-F) according to season. The dominant species were Ulva pertusa, Gelidium divaricatum and Chondrachanthus intermedia in section $\mathrm{A} ; U$. pertusa, G. divaricatum, Chondria crassicaulis and $C$. intermedia in section $\mathrm{B} ; U$. pertusa and $G$. divaricatum in section $\mathrm{C} ; U$. pertusa, $C$. crassicaulis and Sargassum thumbergii in section D; and $U$. pertusa and $G$. divaricatum in section E. Section $F$ formed seagrass bed (Zostera marina) throughout every season. Generalizing this factor shows that the community structure of benthic marine plants at Jijindo Island can be classified into sections $\mathrm{A}$ and $\mathrm{B}$, sections $\mathrm{C}$ and $\mathrm{E}$, section $\mathrm{D}$ and section $\mathrm{F}$ based on the geographical characteristics. The geographical characteristics of Jijindo are as follows: the 1st type is the base rock area with the sand bed in its lower tidal zone (sections A and B); the 2nd type is the terrain with the sand bed in its entire intertidal zone and with rocks distributed on said sand bed (sections $\mathrm{C}$ and $\mathrm{E}$ ); the 3rd type is where the rocky shore is fully formed (section D); and the 4th type is the pond area where the seawater is exchanged and that is composed of a sand bed (section F).

Table 4. The importance value (IV) of benthic marine algae by each season and section, based on coverage and frequency in Jijindo Island, Gwangyang Bay.

\begin{tabular}{|c|c|c|c|c|c|c|c|c|c|c|c|}
\hline \multirow{2}{*}{ No. } & \multirow{2}{*}{ Species } & \multicolumn{5}{|c|}{ Spring } & \multicolumn{5}{|c|}{ Summer } \\
\hline & & $\mathbf{A}$ & B & $\mathbf{C}$ & D & $\mathbf{E}$ & $\mathbf{A}$ & B & $\mathrm{C}$ & D & $\mathbf{E}$ \\
\hline 1 & Ulva pertusa & 34.4 & 26.3 & 65.4 & 29.3 & 25.1 & 9.8 & 42.2 & 25.8 & 30.0 & 21.5 \\
\hline 2 & Gelidium divaricatum & 21.1 & 13.0 & 17.2 & 5.8 & 44.1 & 82.1 & 51.5 & 41.2 & 6.8 & 69.2 \\
\hline 3 & Chondria crassicaulis & 1.6 & 27.0 & - & 3.1 & 2.9 & - & 1.9 & - & 0.6 & - \\
\hline 4 & Sargassum thunbergii & - & 5.5 & - & 25.0 & - & - & 3.1 & 33.1 & 37.6 & - \\
\hline 5 & Chondracanthus intermedia & 7.1 & 18.7 & - & 0.3 & - & - & 0.7 & - & - & - \\
\hline 6 & Hizikia fusiformis & - & - & - & 3.5 & - & - & - & - & 1.3 & - \\
\hline 7 & Corallina spp. & - & - & - & 2.8 & - & - & - & - & 4.9 & - \\
\hline 8 & Porphyra sp. & - & - & - & - & 23.0 & - & - & - & - & - \\
\hline 9 & Chondrus ocellatus & 14.5 & 0.4 & 8.9 & 2.0 & - & - & - & - & - & - \\
\hline 10 & Melobesioidean algae & - & - & - & 4.1 & - & - & - & - & 6.7 & - \\
\hline 11 & Undaria pinnatipida & 12.3 & - & 0.5 & 10.0 & - & - & - & - & - & - \\
\hline 12 & Laurencia sp. & - & - & 1.6 & 1.1 & - & 8.1 & - & - & 11.5 & - \\
\hline 13 & Polysiphonia sp. & - & - & - & 0.2 & 2.1 & - & - & - & - & $\cdot$ \\
\hline 14 & Colpomenia sinuosa & 4.6 & 1.7 & - & 0.1 & 2.9 & - & - & - & - & - \\
\hline 15 & Caulacanthus ustulatus & - & - & - & - & - & - & - & - & - & 9.3 \\
\hline 16 & Ahnfeltiopsis flabelliformis & - & - & - & 0.5 & - & - & - & - & 0.3 & - \\
\hline 17 & Sargssum fluvellum & - & 7.1 & 0.5 & 0.4 & - & - & - & - & - & - \\
\hline 18 & Gelidium amansii & - & - & - & 4.0 & - & - & 0.7 & - & - & - \\
\hline 19 & Acrosorium polyneurum & 1.6 & 0.4 & - & 0.4 & - & - & - & - & - & - \\
\hline 20 & Grateloupia elliptica & - & - & 5.2 & - & - & - & - & - & - & - \\
\hline 21 & Lomentaria hakodatensis & - & - & - & - & - & - & - & - & - & - \\
\hline 22 & Cladophora sp. & - & - & - & - & - & - & - & - & - & - \\
\hline 23 & Symphyocladia latiuscula & 0.2 & - & - & 0.1 & - & - & - & - & 0.6 & - \\
\hline 24 & Pterocladia capillacea & 2.1 & - & - & 0.3 & - & - & - & - & - & - \\
\hline 25 & Pneophyllum zostericolum & - & - & - & 1.8 & - & - & - & - & - & - \\
\hline 26 & Grateloupia lanceolara & - & - & 0.5 & - & - & - & - & - & - & - \\
\hline
\end{tabular}

(Section F were Zostera marina bed). 
Table 4. Continued.

\begin{tabular}{cccccccccccccccccccc}
\hline \multirow{2}{*}{ No. } & \multicolumn{1}{c}{ Autumn } & \multicolumn{1}{c}{ A } & B & C & D & E & & A & B & C & D & E & & A & B & C & D & E & Sum \\
\hline 1 & 11.3 & 37.8 & 57.9 & 25.5 & 76.8 & 17.8 & 15.9 & 53.9 & 22.4 & 34.3 & 18.3 & 30.5 & 50.7 & 26.8 & 39.4 & 165.8 \\
2 & 41.4 & 20.9 & 37.3 & 2.9 & 22.4 & 38.2 & 20.7 & 28.2 & 4.4 & 49.3 & 45.7 & 26.5 & 31.0 & 5.0 & 46.3 & 154.5 \\
3 & 10.9 & 27.4 & 0.5 & 22.4 & - & 16.3 & 33.8 & 6.3 & 20.3 & 6.3 & 7.2 & 22.5 & 1.7 & 11.6 & 2.3 & 45.3 \\
4 & 0.3 & 1.7 & - & 11.5 & - & - & 5.3 & - & 30.5 & - & 0.1 & 3.9 & 8.3 & 26.1 & - & 38.4 \\
5 & 22.2 & 9.7 & 1.0 & - & - & 17.9 & 14.0 & 1.1 & - & - & 11.8 & 10.8 & 0.5 & 0.1 & - & 23.2 \\
6 & 8.9 & 0.9 & - & 7.2 & - & 5.5 & 3.3 & - & 2.2 & 2.2 & 3.6 & 1.1 & - & 3.6 & 0.5 & 8.8 \\
7 & - & - & - & 8.8 & - & - & - & - & 13.8 & - & - & - & - & 7.6 & - & 7.6 \\
8 & - & - & - & - & 0.8 & 0.3 & 0.4 & 0.5 & 0.8 & 3.1 & 0.1 & 0.1 & 0.1 & 0.2 & 6.7 & 7.2 \\
9 & - & - & - & - & - & - & - & 1.6 & 0.0 & 0.5 & 3.6 & 0.1 & 2.6 & 0.5 & 0.1 & 7.0 \\
10 & 1.7 & 1.3 & 1.9 & 9.0 & - & - & 0.4 & - & 1.2 & - & 0.4 & 0.4 & 0.5 & 5.3 & - & 6.6 \\
11 & - & - & - & - & - & - & 3.2 & - & - & - & 3.1 & 0.8 & 0.1 & 2.5 & - & 6.5 \\
12 & - & - & - & 0.4 & - & - & - & - & - & - & 2.0 & - & 0.4 & 3.2 & - & 5.7 \\
13 & - & - & - & 1.1 & - & - & - & 5.2 & 1.0 & 2.2 & - & - & 1.3 & 0.6 & 1.1 & 3.0 \\
14 & - & - & - & - & - & 0.6 & 0.4 & - & & 0.9 & 1.3 & 0.5 & - & - & 0.9 & 2.8 \\
15 & - & - & - & - & - & - & - & - & - & - & - & - & - & - & 2.3 & 2.3 \\
16 & - & - & - & 6.2 & - & - & - & - & 0.5 & 1.3 & - & - & - & 1.9 & 0.3 & 2.2 \\
17 & - & - & - & - & - & - & - & - & - & - & - & 1.8 & 0.1 & 0.1 & - & 2.0 \\
18 & - & - & - & - & - & 1.4 & 1.3 & 0.5 & - & - & 0.4 & 0.5 & 0.1 & 1.0 & - & 2.0 \\
19 & 0.3 & - & 0.5 & 0.6 & - & 0.9 & 0.8 & 1.1 & - & - & 0.7 & 0.3 & 0.4 & 0.3 & - & 1.7 \\
20 & - & - & - & 0.4 & - & 0.6 & - & - & - & - & 0.1 & - & 1.3 & 0.1 & - & 1.6 \\
21 & 2.7 & 0.4 & - & 0.2 & - & - & - & 1.1 & 0.3 & - & 0.7 & 0.1 & 0.3 & 0.1 & - & 1.2 \\
22 & 0.3 & - & - & 3.3 & - & - & - & - & - & - & 0.1 & - & - & 0.8 & - & 0.9 \\
23 & - & - & - & 0.3 & - & 0.3 & 0.4 & - & 1.0 & - & 0.1 & 0.1 & - & 0.5 & - & 0.7 \\
24 & - & - & - & 0.2 & - & - & - & - & - & - & 0.5 & - & - & 0.1 & - & 0.7 \\
25 & - & - & - & - & - & - & - & - & 0.3 & - & - & - & - & 0.5 & - & 0.5 \\
26 & - & - & 1.0 & - & - & - & - & 0.5 & - & - & - & - & 0.5 & & - & 0.5 \\
\hline
\end{tabular}

As the results indicate, the dominant species of the marine plant community of Jijindo Island were 6 species in particular: Ulva pertusa, Gelidium divaricatum, Chondria crassicaulis, Sargassum thunbergii and Chondrachanthus intermedia with Zostera marina forming on the bed in section $\mathrm{F}$.

The zonation pattern of the marine algal community according to coverage is shown in Fig. 3. The Chlorophyta showed high coverage in the middle and lower intertidal zone every season, but was especially high in spring. The Phaeophyta also showed high coverage both in the middle and lower zones, but were mainly high in the middle, and it was higher in spring than in the other seasons. The Rhodophyta was distributed through all intertidal zones, but its coverage was high in the lower zone every season except for summer.
The macro-zoobenthic community consists of Anthopleura midori, Chlorostoma turbinata, Chthamalus challengeri, Crassostrea gigas, Liolophura japonica, Littorina brevicula, Mytilus edulis, Omphalius pfeifferi pfeifferi and Reishia clavigera. On the other hand, the coverage-based vertical zonation change along the rocky shore of macro-zoobenthos according to season is shown in Fig. 4. C. challengeri was dominant in the upper and middle intertidal zones with little change according to season in comparison with other species. $L$. brevicula was dominant basically between the upper and middle zone. $M$. edulis was dominant in the middle and lower intertidal zones with juvenile population (spat) distributed in the upper part of the middle zone and with the highest coverage in spring. C. gigas showed a zonation pattern similar to $M$. edulis with high coverage in summer. 

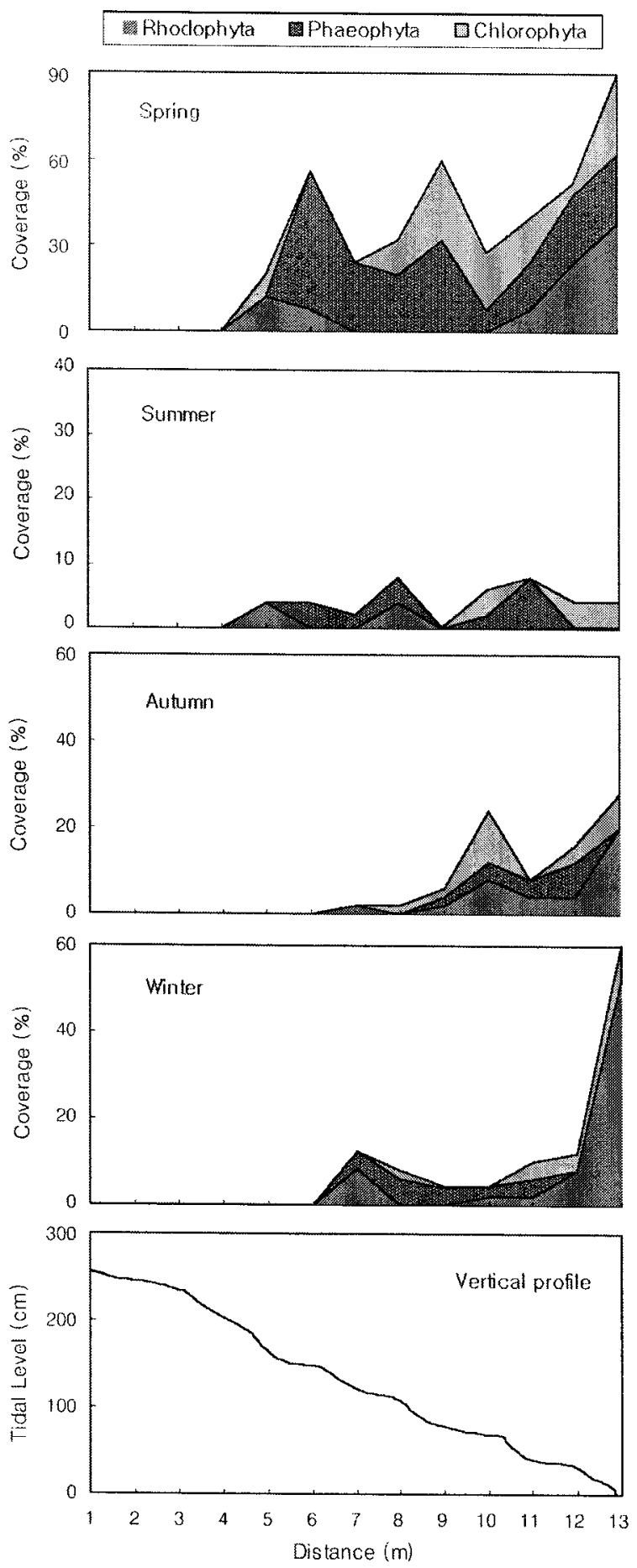

Fig. 3. Seasonal coverage variation of vertical distribution patterns of benthic marine algae along the line transect in Jijindo Island, Gwangyang Bay.

The algal species diversity indices for each season were estimated according to coverage, frequency, sum of coverage and frequency, and importance value (Fig. 5). The species
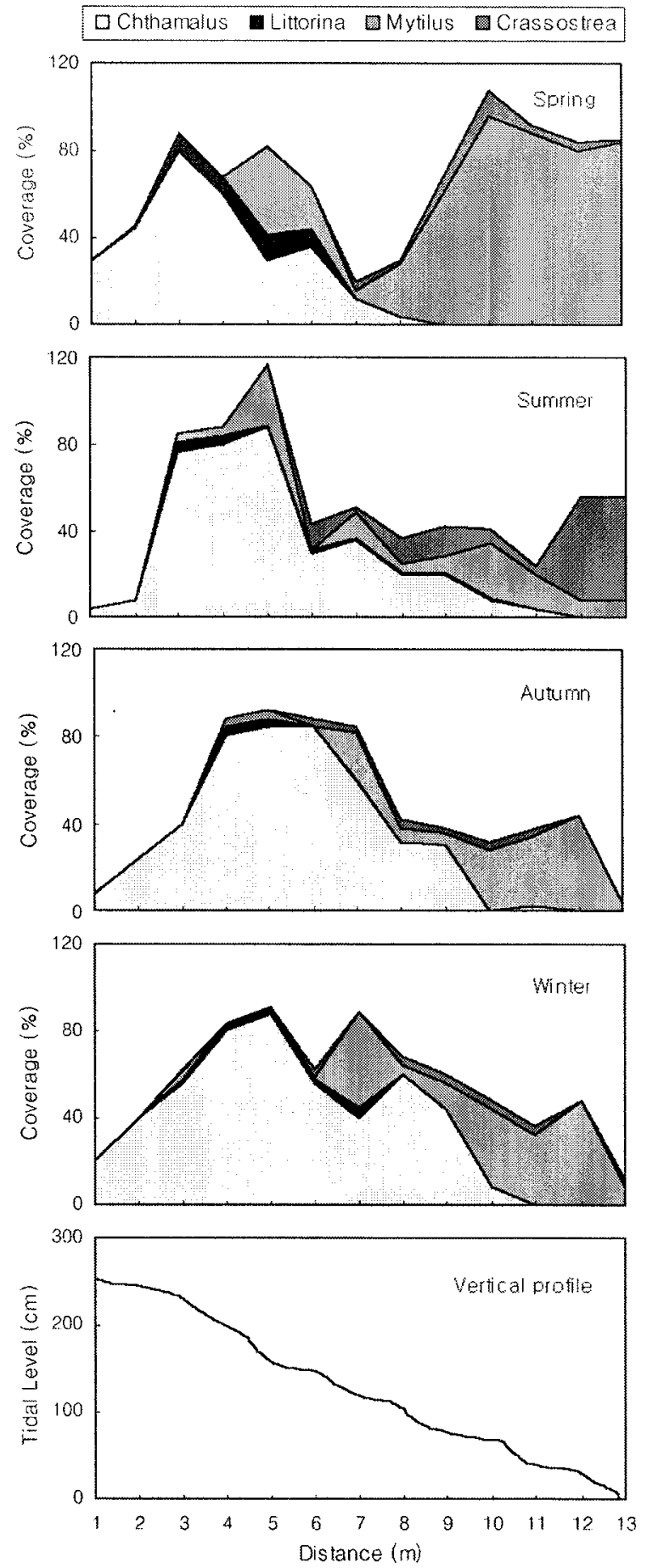

Fig. 4. Seasonal coverage variation of vertical distribution patterns of macro-zoobenthic community according to species on the coverage of major macrozoobenthos investigated in each quadrat along the line transect in Jijindo Island, Gwangyang Bay. (Chthamalus: Chthamalus challegeri, Crassostrea: Crassostrea gigas, Littorina: Littorina brevicula, Mytilus: Mytilus edulis). 


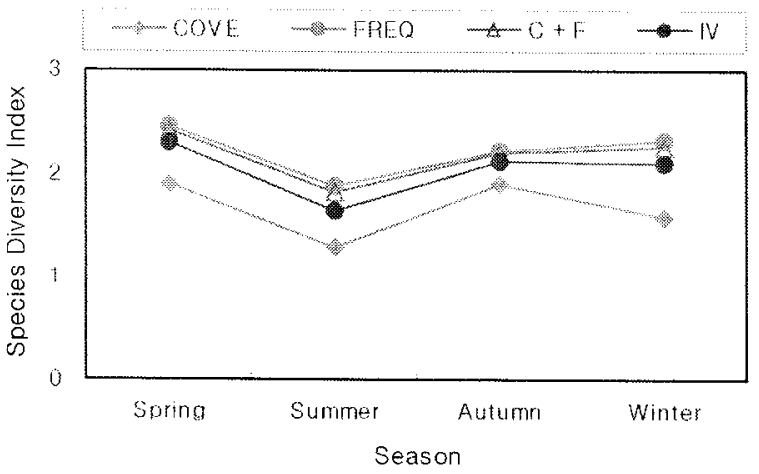

Fig. 5. Comparison of species diversity index $\left(\mathrm{H}^{\prime}\right)$ of marine benthic algal community from difference source data in Jijindo Island, Gwangyang Bay. (COVE: coverage, FREQ: frequency, $\mathrm{C}+\mathrm{F}$ : sum of frequency and coverage, IV: importance value).

diversity index based on coverage was 1.67 (1.29-1.90); the figure 2.22 (1.88-2.46) was derived from frequency; $2.17(1.82-2.42)$ was derived from the sum of coverage and frequency; and 2.04 (1.64-2.29) from the importance value. The variation in algal diversity according to season was high in spring and low in summer, excluding the coverage criterion. The value differed according to the source date for estimating the algal diversity index. The algal diversity index tended to be low based on data related to coverage, but high in terms of frequency.

\section{Discussion}

In the southern coast of Korea, the total algal species was 560 composed of 37 Cyanophyta species $(6.6 \%), 73$ Chlorophyta species (13.0\%), 112 Phaeophyta species (20.4\%) and 336 Rhodophyta species (Yoo 2003). In the previous report for Gwangyang Bay, the percentage of divisional algal composition was similar to that of the southern coast (Lee and Kim 1977; Song 1986; Kim et al. 1991). Comparing such data with the results of this study shows that the composition rate of Cyanophyta and Phaeophyta has mildly decreased, while that of Rhodophyta increased. The algal species of Gwangyang Bay were reported to be at 129 in the investigation conducted by Lee and Kim (1977) in 1974-1975 before industrial development; 171 by Song (1986) in 1983-1985 during the early stages of the Gwangyang Steelworks construction period; and 124 by Kim et al. (1991) in 1990. Such data looks very different from the investigation conducted at this time, where 85 species were verified. Besides, Song (1986) reported that the algal species diversity consisted of a maximum of 2.9 at Myodo inside Gwangyang Bay and 4.0 at Hangumi, which is located at the bay entrance. This result is higher than the result gained at this time, which shows that the algal community structure has progressed toward simplification in comparison with the past. The similarity index is $0.49-0.56$ comparing the algal community of the present and that of previous studies (Lee and Kim 1977; Song 1986; Kim et al. 1991) and 0.62-0.69 comparing communities in the previous results. This data shows that the community has changed. In the study on the polychaete community of Gwangyang Bay, Jung et al. $(1995,1997)$ reported that the broad scale reclamation and dredging activities affected changes in the community structure and dominant species composition. Based on this report, I think that the algal species might have declined due to the industrialization of this local area, which began early in the 1980 s.

Lee et al. (1975) divided the inside of Gwangyang Bay into three sections to report on the characteristics of the algal community. They reported that Ulva pertusa, Sargassum thunbergii and Chondria crassicaulis were the common dominant species, adding Gelidium divaricatum and Gelidium pusillum to Section I; Hizikia fusiformis and Carpopeltis affinis to Section II. Song (1986) reported that according to algal zonation G. divaricatum, Ulva conglobata and Eenteromorpha compressa were dominant in the upper intertidal zone; S. thunbergii and Ectocarpus arctus in the middle zone; and U. pertusa, Corallinaceae, $C$. crassicaulis and Undaria pinnatifida in the lower zone. The dominant species reported in the present study complies only with $G$. divaricatum, $S$. thunbergii, $U$. pertusa, and $C$. crassicaulis among the dominant species reported by them. Whereas, reporting on the whole algal community on the southern coast, Yoo and Lee (1980) distinguished the western area as the Ishige sinicola Ishige okamurae association and the eastern area as the Colpomenia - Ecklonia association. Kang et al. (1993) reported that the southern islands area was represented by Gloiopeltis spp., Corallina pilulifera, Laurenciea spp. and Sargassum sagamianum among the 14 dominant species. These results came from the investigation conducted in summer and could not represent the whole algal community. But these results are much different from the results of the investigation conducted at this time. In this study area, $U$. pinnatifida was dominant in the subtidal zone, whereas the intertidal zone population was excluded due to collection of sample species by local residents. The collection disturbance often occurs in many habitats. Therefore, I think that human interference in the production of economic 
algae should be referred to in order to predict the correct nature of the algal community in the future.

This study shows that the macro-zoobenthic community is represented by Chthamalus challengeri in the upper intertidal zone and Mytilus edulis and Crassostrea gigas in the middle and lower zones. Yoo (2003a) reported that $C$. challengeri was dominant in the upper zone and $M$. edulis in the middle zone at Dongbaeksum, Busan. Based on this report, I guess that the macro-zoobenthic organisms, including $C$. gigass, have not appeared in great profusion in the lower intertidal zone at Dongbaeksum, which is related with the species competition in the lower zone as well as with the characteristics of this local area.

Seeing both marine plants and macro-zoobenthos communities, the biological zonation of the intertidal zone in Gwangyang Bay is represented by $C$. challengeri and $G$. divaricatum in the upper intertidal zone; $M$. edulis, $C$. gigas and $U$. pertusa in the middle zone; and $M$. edulis, $C$. gigas, $U$. pertusa, C. crassicaulis, $S$. thunbergii and $C$. intermedia in the lower zone. And the zoobenthos community showed the lower species diversity than marine plants, while showing that the coverage was relatively higher.

Finally, the area in which the coastal environment has largely changed, for example Gwangyang Bay, requires regular investigation on the benthic communities, such as marine plants and macro-zoobenthos so that you can understand how environmental change would affect the community structure. Besides, in order to determine whether the current change in biodiversity and structure of marine benthic communities is a global matter or a local matter that has occurred since Korea began to be industrialized, it is necessary to organize a research team specially for this study in every environmentally significant area and secure particular and integrated guidelines on the community analysis as Yoo (2003b) described. I think also that securing the raw data obtained through the investigations, which have been conducted until now, would be very important in understanding the succession of marine benthic communities now underway. I expect that such efforts would make it possible to set up a particular strategy for biodiversity conservation and secure correct information on the marine bioresources from a national point of view.

\section{Acknowledgements}

I wish to express my appreciation to the Environment Research Team of RIST for the satellite picture of Gwangyang Bay. Comments from Prof. Y.H. Kim and Dr. H. Chung are gratefully acknowledged. This work was supported by the Korea Research Foundation Grant (KRF-2002-005-F00004).

\section{References}

Blake, N.J., L.J. Doyle, and T.E. Pyle. 1976. The macrobenthic community of a thermally altered area of Tampa Bay, Florida. p. 296-301. In: Thermal Ecology II. ed. by G.W. Esch and R.W. McFarlane. Technical Information Center. Energy Research and Development Administration.

Chang, J., Y.H. Han, K.D. Yoon, and Y.L. Yang. 1975. Some Physical Oceanographic Research on the Kwang Yang Bay. Rep. Min. Sci. \& Tech. STF-74-6, p. 49-71.

Huh, S.-H. and Y.-R. An. 1997. Seasonal variation of Shrimp (Crustacea: Decapoda) community in the eelgrass (Zostera marina) bed in Kwangyang Bay, Korea. $J$. Korean Fish. Soc., 30, 532-542.

Jung, R.-H., J.-S. Hong, and J.-H. Lee. 1995. Temporal changes of community structure in two subtidal polychaete assembleges in Kwang-yang Bay, Korea. J. Korean Soc. Oceanogr., 30, 390-402.

Jung, R.-H., J.-S. Hong, and J.-H. Lee. 1997. Spatial and seasonal patterns of polychacte community during the reclamation and dredging activities for the construction of the Pohang Steel Mill Company in Kwangyang Bay, Korea. J. Korean Fish. Soc., 30, 730-743.

Kang, R.S., J.G. Je, and J.S. Hong. 1993. Summer algal communities in the rocky shore of the south sea of Korea. I. intertidal communities. Bull. Korean Fish. Soc., 26, 49-62.

Kim, K.Y., D.S. Choi, and I.K. Lee. 1991. Marine algal flora of Kwangyang Bay, the south coast of Korea. Proc. Coll. Natur. Sci. SNU, 16, 9-24.

Lee, I.K. and Y.H. Kim. 1977. A study on the marine algae in the Kwang Yang Bay. 3. The marine algal flora. Proc. Coll. Natur. Sci., SNU, 2, 113-153.

Lee, I.K., Y.H. Kim, J.H. Lee, and S.W. Hong. 1975. A study on the marine algae in the Kwang Yang Bay. 1. The seasonal variation of algal community. Korean $J$. Bot., 18, 109-121.

Park, Y.A., C.-B. Lee, and J.H. Choi. 1984. Sedimentary environments of the Gwangyang Bay, southern coast of Korea. J. Oceanol. Soc. Korea, 19, 82-88.

Peet, R.K. 1974. The measurement of species diversity. Ann. Rev. Ecol. Syst., 5, 285-307.

Reddy, M.V. and B.M. Rao. 1991. Benthic macroinvertebrates as indicators of organic pollution of aquatic ecosystems in a semi-arid tropical urban system. p. 65-78. In: Bioindicators and Environmental Management. ed. by D.W. Jeffrey and B. Madden. Academic Press, San Diego.

Shannon, C.E. and W. Weaver. 1949. The Mathematical Theory of Communication. Board of Trustees of Univ. III. Urbana. $117 \mathrm{p}$.

Shin, H.C. and C.-H. Koh. 1990 Temporal and spatial varia- 
tion of polychaete community in Kwangyang Bay, southern coast of Korea. J. Oceanol. Soc. Korea, 25, 205-216.

Song, C.B. 1986. An ecological study of the intertidal macroalgae in Kwangyang Bay, southern coast of Korea. Korean J. Phycol., 1, 203-223.

Sprensen, T. 1948. A method of establishing groups of equal amplitude in plant sociology based on similarity of species content. Biol. Skr., K. danske Vidensk Selsk, 5, 1-34.

Yoo, J.S. 2003a. Biodiversity and community structure of marine benthic organisms in the rocky shore of Dongbaekseom, Busan. Algae, 18, 225-232.
Yoo, J.S. 2003b. Dynamics of marine benthic community in the intertidal zone of Seoam, Busan. The Sea, 8, 420-425.

Yoo, K.D. 2003. Species Diversity and Database Construction of Marine Algae in Korea. M.S. Thesis. CNU, Cheongju. $106 \mathrm{p}$.

Yoo, S.A. and I.K. Lee. 1980. A study on the algal communities in the south coast of Korea. Proc. Coll. Natur. Sci., $S N U, 5,109-138$. 